\title{
State-Of-The-Art Review of Geosynthetic Clay Liners
}

\author{
De-Jun Kong ${ }^{1,2}$, Huai-Na Wu ${ }^{1,2, *}$, Jin-Chun Chai ${ }^{3}$ and Arul Arulrajah ${ }^{4}$ \\ 1 State Key Laboratory of Ocean Engineering and Department of Civil Engineering, \\ School of Naval Architecture, Ocean, and Civil Engineering, Shanghai Jiao Tong University, \\ Shanghai 200240, China; kongdejun@sjtu.edu.cn \\ 2 Collaborative Innovation Center for Advanced Ship and Deep-Sea Exploration (CISSE), \\ Shanghai Jiao Tong University, Shanghai 200240, China \\ 3 Department of Civil Engineering, School of Naval Architecture, Ocean, and Civil Engineering, \\ Shanghai Jiao Tong University, Shanghai 200240, China; jcchai@sjtu.edu.cn \\ 4 Department of Civil and Construction Engineering, Swinburne University of Technology, Hawthorn, \\ VIC 3122, Australia; aarulrajah@swin.edu.au \\ * Correspondence: wu-hn@sjtu.edu.cn; Tel.: +86-21-3420-4301; Fax: +86-21-6419-1030
}

Received: 13 October 2017; Accepted: 11 November 2017; Published: 16 November 2017

\begin{abstract}
An important component of modern landfills is the liner system for the prevention of leachate contamination of surrounding ground. Among landfill liner systems, geosynthetic clay liner (GCL) has gained widespread popularity across the world because of its lower hydraulic conductivity as well as its ability to self-heal local damage, which is almost unavoidable in the field. Over the past few decades, numerous studies have been conducted to examine the performance of GCLs, particularly in regard to hydraulic conductivity, chemical compatibility, water-swelling, self-healing capacity, diffusion characteristics, gas migration, and mechanical behavior. In this paper, a brief introduction on modern GCL products is firstly given. Subsequently, the main findings of previous publications on the critical properties influencing the long-term performance of GCLs are summarized in a comprehensive manner. Finally, further research perspectives on polymer-treated GCLs are presented. This paper provides general insights that help readers gain a state-of-the-art overview of GCLs and trends for future development.
\end{abstract}

Keywords: geosynthetic clay liner; engineering characteristics; bentonite; polymer-treated GCL

\section{Introduction}

Solid waste, which includes waste generated from mining, industrial and agricultural operations, urban construction [1-3], and community activities, commonly contains a variety of contaminants that may pose significant hazards to public health and the environment. In order to minimize the environmental impact, solid wastes generally require disposal in either a physical (e.g., crush, compaction, combustion) or a biogeochemical manner (e.g., composting, incinerating). No matter which treatment method is adopted, disposal by land-filling is often the eventual fate for most solid waste via cutoff from surrounding groundwater system [4-10]. In developed countries, the development of land-filling can be divided into three stages [11]: (i) the direct dumping of waste before the 1940s; (ii) sanitary landfills from the 1940s to 1970s, in which the waste was covered by dirt with no barrier liner; (iii) closed landfills after the 1970s, which had barrier liner systems to limit contaminant migration into the surrounding environment.

The barrier system is a critical component of modern closed landfills. In the early 1980s, the barrier system of a landfill mainly comprised of compacted clay liner (CCL). This was progressively substituted by geomembrane (GM) by the end of 1980s. Since the 1990s, the composite liner system GCL (geosynthetic clay liner) has gained widespread popularity. The geosynthetic clay liner is composed of a layer of bentonite supported or encased by geotextiles or geomembranes. Compared to the 
compacted clay liners and geomembranes, GCLs have a variety of advantages, such as low hydraulic conductivity, high mechanical behavior, and simple and rapid installation in the field. Moreover, the high-swelling capability of bentonite in GCL enables local damage caused by field installation to self-heal in some circumstances. Owing to these advantages, GCLs are also adopted in many other geotechnical applications, such as dams, artificial lakes, sewage-treatment ponds, storage tanks, landfills, contaminated sites, etc. [12-21].

Over the past three decades, extensive studies have been conducted on the physical and mechanical properties of GCL and/or bentonite-based barriers in geoenvironmental applications [22-28]. Generally, the properties of GCLs have been investigated according to the following aspects: (i) hydraulic conductivity and chemical compatibility; (ii) self-healing capacity; (iii) diffusion; (iv) gas migration; and (v) mechanical behaviours, e.g., creep behavior [29]. These properties are closely related to bentonite's form and mineralogy, which have also received much attention in the past decade. Moreover, due to the increased application of GCL materials in mining and industrial processes (e.g., heap leach pads etc.), many studies have been conducted to investigate the effect of exposure to extreme environments and conditions (i.e., excessive cold, excessive heat, hyper-salinity, strongly acidic, strongly alkaline, etc.). To better deal with these effects, the modification of bentonite also became a research hotspot. One of the typical innovations is polymer-treated bentonites in GCLs [30-32]. The objectives of this paper are: (i) to provide a comprehensive summary on the main findings on the above-mentioned five aspects of GCLs over the past few decades; (ii) to provide perspectives for further studies, e.g., polymer-treated GCLs.

\section{Configuration of Geosynthetic Clay Liners}

Figure 1 shows a typical liner system in a municipal waste landfill with the configuration of the covering and bottom liners, which are generally composed of geomembrane, geotextile and other geomaterials. GCL is one of the most important impermeable materials in the liners. GCL comprises a layer of bentonite supported by a geomembrane or sandwiched between two geotextiles. The thickness of a GCL is typically $5 \mathrm{~mm}$ to $12 \mathrm{~mm}$. According to the type of geosynthetics adopted, GCL can be divided into the following two categories: (i) GT-GCL (geotextile-encased GCL), which is composed of two geotextiles and a thin bentonite layer sandwiched between them, mechanically held together by method of needle punching, stitching or chemical adhesives; (ii) GM-GCL (geomembrane-supported GCL), which comprises of a layer of geomembrane and a layer of bentonite pasted to it using non-polluting adhesive [33]. The photos for various types of GCL are given in Figure 2.

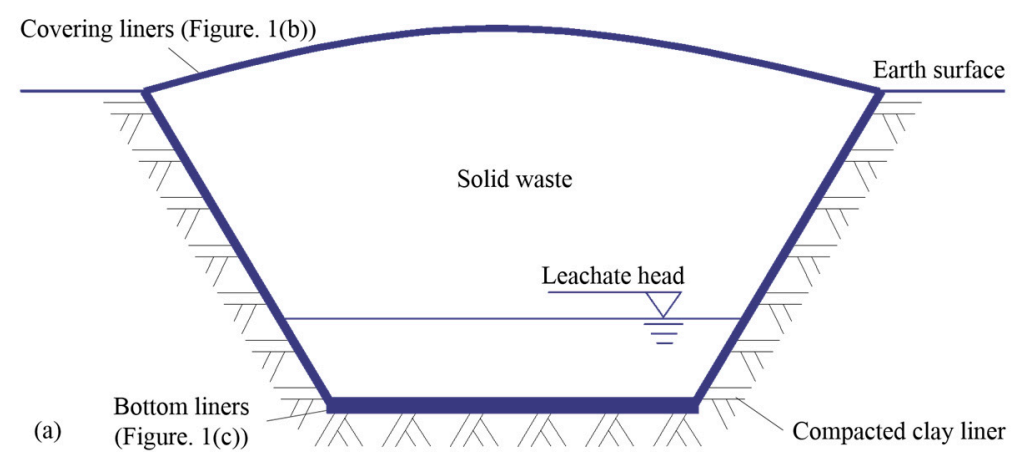

Figure 1. Cont. 

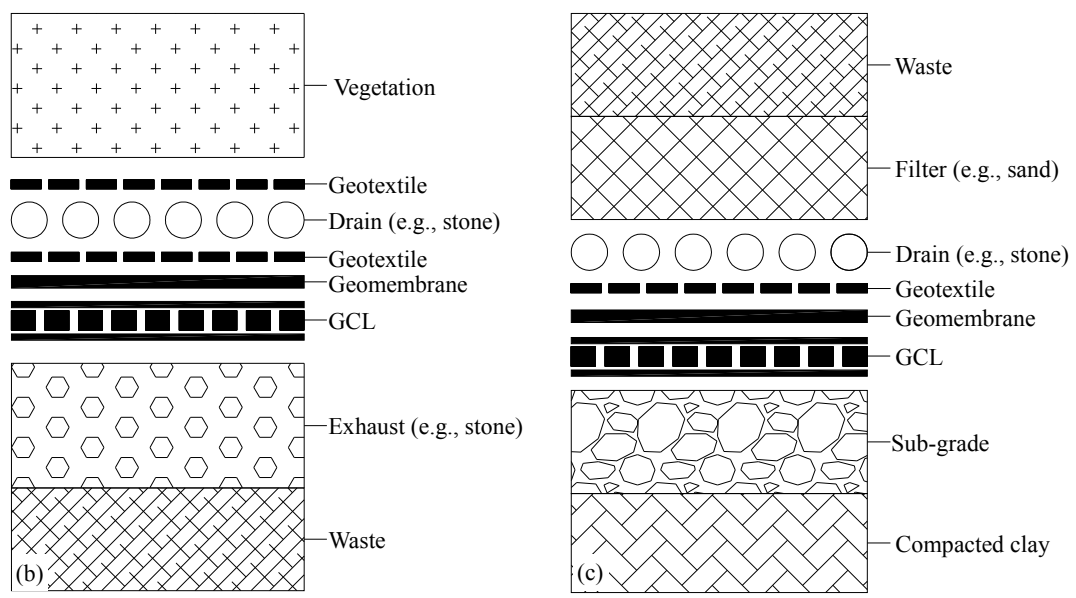

Figure 1. Structure of a typical landfill: (a) schematic of a typical landfill (modified from Du et al., 2009) [28]; (b) structure of covering liners; (c) structure of bottom liners.
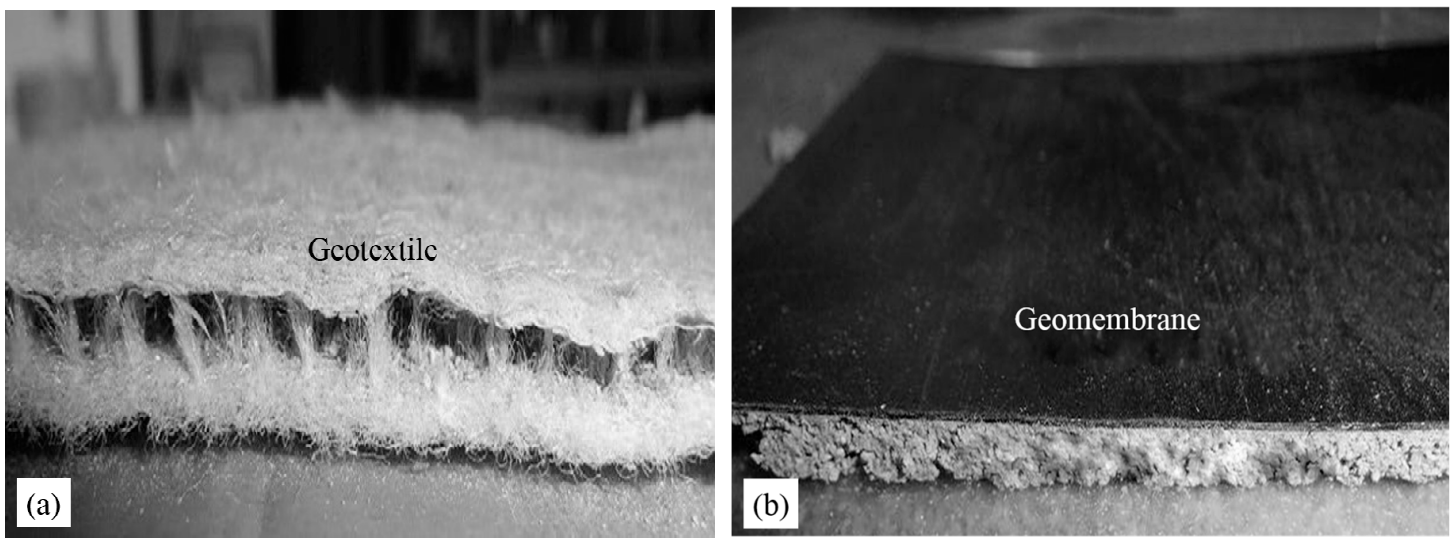

Figure 2. Basic types of geosynthetic clay liners (GCLs): (a) geotextile-encased (GT-GCL); and (b) geomembrane-supported (GM-GCL).

Figure 3 schematically illustrates the configurations of the GCLs, including three types of GT-GCL (needle-punched, stitched-bonded, and adhesive-bonded) and one type of GM-GCL. The needle-punching method of GT-GCL involves piercing fibers from upper geotextile to the bottom geotextile. These fibers extend through the bentonite and rely on natural entanglement or being fused (called "thermal lock") to the bottom geotextile in order to bond the GCL together. The stitching method of GT-GCL is to sew the geotextiles and bentonite together by using stitching-bonded yarns. The pasting method of GT-GCL is to incorporate non-polluting adhesive into bentonite and then paste on two layers of geotextiles. This method creates a relatively lower bonding strength than the needle-punching or stitching methods. For GM-GCL, the bentonite mixed with adhesive is pasted to one layer of geomembrane. In order to provide primary protection during installation, a thin layer of geotextile is also adhered on to the surface of bentonite.

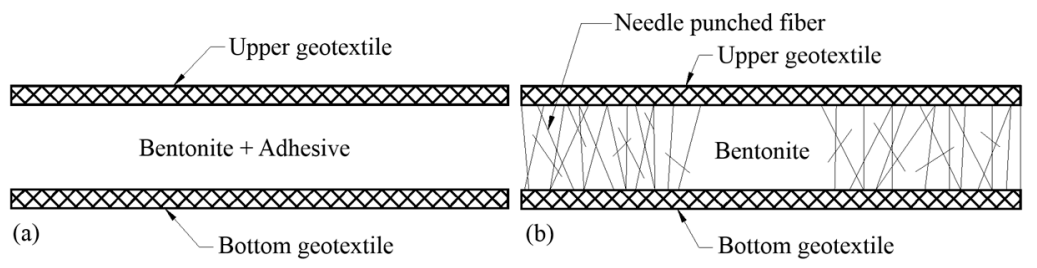

Figure 3. Cont. 


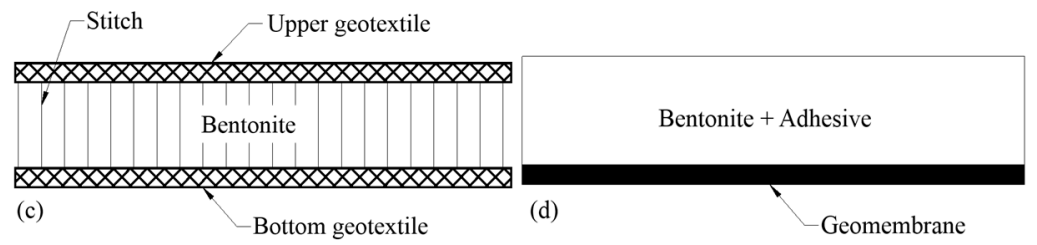

Figure 3. Configurations of GCLs: (a) GT-GCL (needle-punched); (b) GT-GCL (stitched-bonded); (c) GT-GCL (adhesive-bonded); (d) GM-GCL (adhesive-bonded); (modified from Koerner, 2005) [34].

The bentonite in GCL has extremely low hydraulic conductivity and high swelling capacity. Bentonite has a high creep behavior to keep the hydraulic conductivity of GCL low [35-42]. For a GT-GCL, the role of the bentonite is to reduce the hydraulic conductivity of GCL and to repair local damage. For a GM-GCL, since the geomembrane has a very low hydraulic conductivity, the main function of the bentonite is to repair local damage. The bentonites commonly used in GCLs are: (i) sodium bentonite, and (ii) calcium bentonite. Calcium bentonite has a higher hydraulic conductivity than sodium bentonite. In engineering practice, calcium bentonite is usually treated with sodium compounds such as sodium carbonite prior to use in order to reduce its hydraulic conductivity [43-45].

\section{Properties of GCLs}

\subsection{Hydraulic Conductivity and Chemical Compatibility}

Working as a hydraulic barrier, hydraulic conductivity is the most critical parameter to evaluate the effectiveness of the GCLs. Generally, the barrier effect of GCL is achieved by the bentonite within it, which has extremely low hydraulic conductivity similar to that used in the lubricant in pipe jacking [46]. The only exception is GM-GCL in which geomembrane acts as the water barrier.

Bentonite is basically composed of smectite, whose crystal structure consists of a layer of aluminium-oxygen (or magnesium-oxygen) octahedron, $\left(\mathrm{Al}_{2}(\mathrm{OH})_{6}, \mathrm{Mg}_{3}(\mathrm{OH})_{6}\right)$, sandwiched between two layers of silicon-oxygen tetrahedral $\left(\left(\mathrm{Si}_{4} \mathrm{O}_{10}\right)^{4-}\right)$. Each clay sheet is composed of several or dozens of these structure cells, and layers of structure cells are connected to each other via Van der Waals force. These connections are comparatively weak so that the water molecules can intervene easily, causing swelling of the smectite on the macro level. Figure 4 gives an illustration of the crystal structure of smectite and the crystalline-swelling mechanism.
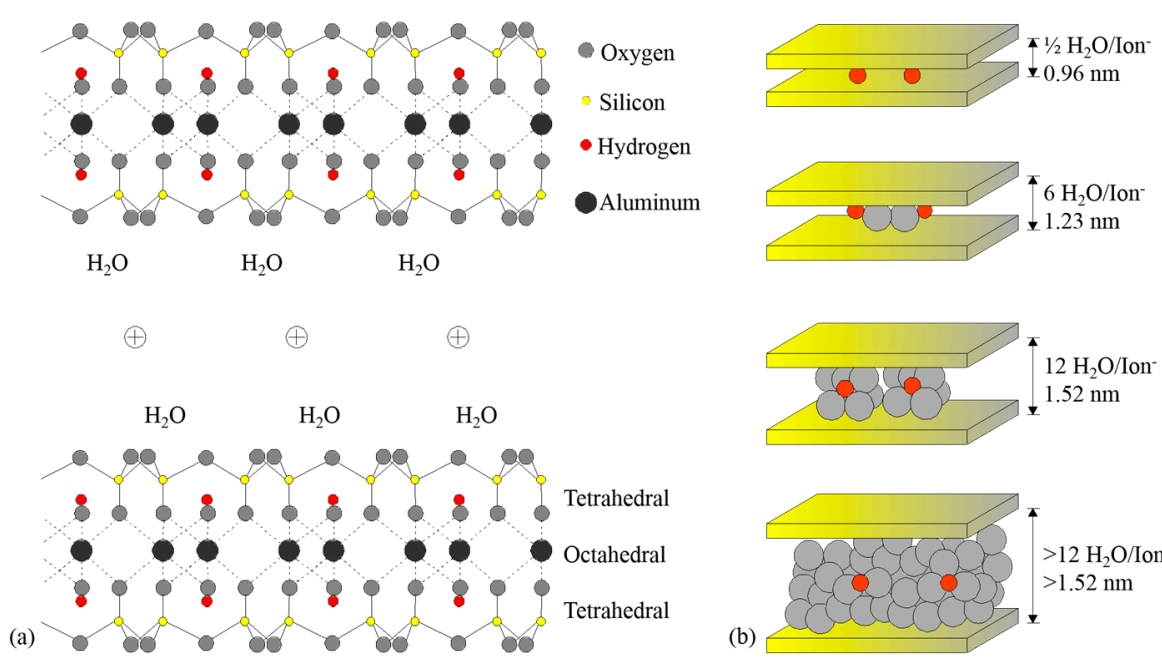

(b)

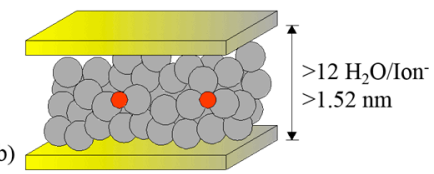

Figure 4. Smectite: (a) crystal structure of smectite [47]; (b) crystalline-swelling mechanism (modified from Ruedrich, et al., 2011) [48]. 
The smectite has high specific surface area, e.g., about $800 \mathrm{~m}^{2}$ for $1 \mathrm{~g}$ of smectite, and a vast number of negative charges on it. To achieve charge balance, the surface will adsorb the cations in the pore water, forming a "diffuse double layer" (DDL) [49-51]. Figure 5 gives an illustration of the typical diffuse double layer. The thickness of DDL $(H)$ can be calculated by the equation proposed by Bolt (1956) [52]:

$$
H=\sqrt{\frac{D k T}{8 \pi n \varepsilon^{2} v^{2}}}
$$

where, $D=$ dielectric constant of solution; $k=$ Boltzmann constant $\left(k=1.38 \times 10^{-23} \mathrm{~J} / \mathrm{K}\right) ; T=$ absolute temperature; $n=$ molar concentration; $\varepsilon=$ elementary charge $\left(\varepsilon=4.8 \times 10^{-20} \mathrm{esu}\right)$; and $v=$ ionic valence. Moreover, electrostatic forces can attract numerous ions into the space between the clay particles, which causes a large difference of ionic concentration between the clay mineral surface and the pore solution. Driven by concentration gradient forces, water with lower electrolyte concentration is taken up by osmosis between the clay particles thus pushing them apart, which makes the smectite further swell.

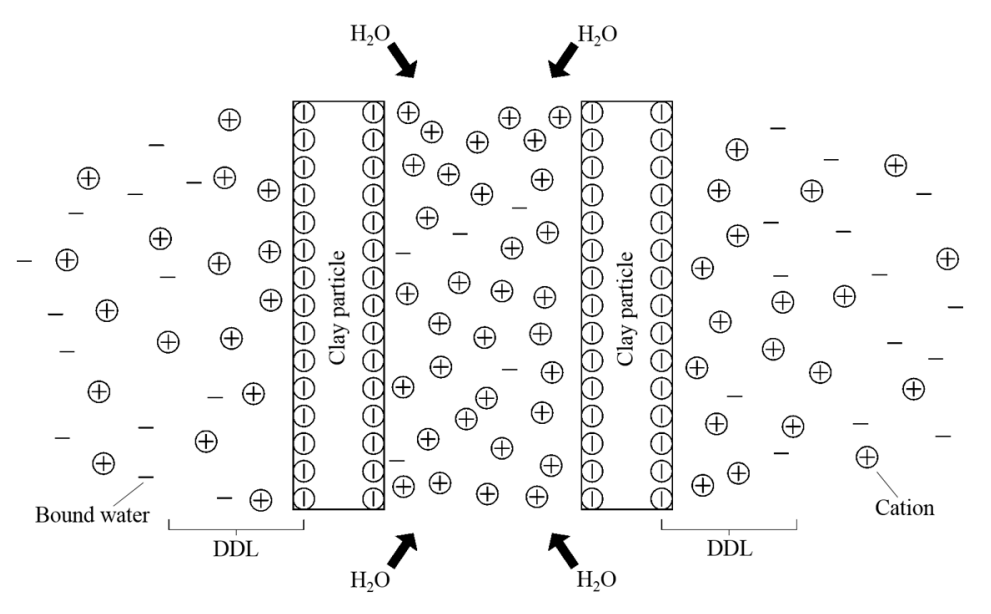

Figure 5. Osmotic swelling of clay minerals (modified from Ruedrich et al., 2011) [48].

After water-swelling, an immobile water phase will be formed by the bound water molecules and an impermeable material will be formed by hydrated bentonite, leading to the decrease of hydraulically active pores, and manifested as anti-seepage of bentonite [30,43,45,53]. Generally, the hydraulic conductivity of bentonite to water is within the range of $2 \times 10^{-12} \mathrm{~m} / \mathrm{s}$ to $2 \times 10^{-10} \mathrm{~m} / \mathrm{s}$, which decreases with the increase in confining pressure $[15,54]$.

In some conditions, if the permeant solution contains high concentrations of cations, especially bivalent cations and trivalent cations (e.g., $\mathrm{Ca}^{2+}, \mathrm{Mg}^{2+}, \mathrm{Al}^{3+}$ ), ion exchange will occur and reach equilibrium, and the thickness of DDL will significantly decrease. This will cause an increase of the hydraulic conductivity of GCL, which can be one order of magnitude or more for some permeating conditions [55-58]. The triggering mechanism of ion exchange on increase of the hydraulic conductivity was presented by Egloffstein (2001) [59]. Figure 6 gives an example of ion exchange between monovalent sodium ions and bivalent calcium ions. The ion exchange increases the inner-crystalline attraction, thus reducing the space between the silicate layers (layers of structure cells) and the mass of bound water. With this change, the micro structure of bentonite changes from smaller, finely distributed clay mineral flakes to larger clay mineral crystals, leading to an increase in hydraulic conductivity. 


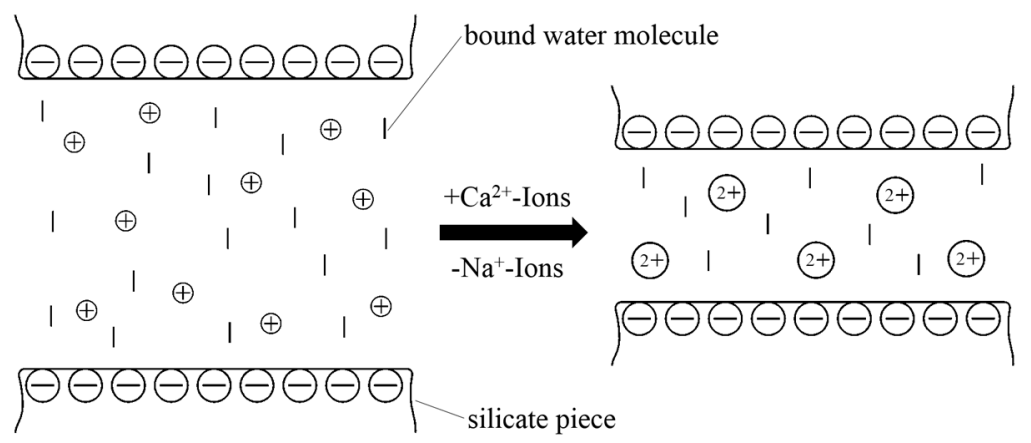

Figure 6. Ion exchange of monovalent sodium ions against bivalent calcium ions in bentonite (modified from Egloffstein, 2001) [59].

GCLs are exposed to leachates other than water under most circumstances. Assessment of the effect of chemical solutions on the hydraulic behaviour of GCLs is of great importance. The hydraulic conductivity to the permeant liquid of GCL needs to be assessed on a case-by-case basis. The common method adopted is the "compatibility test", in which the sample is permeated with a leachate similar to that anticipated. Factors influencing the hydraulic conductivity of GCLs have been studied through extensive compatibility tests $[25,53,55,59-65]$. Generally, the hydraulic conductivity can be affected by both internal and external causes. The internal factors involve the smectite content, aggregate size, exchangeable metals and void ratio of bentonite in GCL, and the external factors include the concentration of cations (monovalent and divalent) in the permeant liquid, pre-hydration of the GCL, etc. In the last 10 years, increasing concern has been expressed about the compatibility of GCLs in extreme environments and conditions, such as hyper-salinity, strongly acidic, strongly alkaline, excessive cold and excessive heat environments, which can greatly deteriorate their anti-seepage performance $[14,61,66-68]$.

\subsection{Self-Healing Capacity}

During field installation, the GCL system may suffer from damage for the following reasons: (i) piercing by sharp objects, e.g., construction machineries [15], angular stones; (ii) poor connections between panels of GCLs [69,70]; (iii) migration of bentonite in GCLs due to daily temperature variation, forming spots/zones with litter or no bentonite [29,56,71,72]; (iv) wet and dry cycles, which leads to the desiccation of clay and associated cracking [73]. Because of its high expansion capacity when hydrated, the bentonite in GCLs can be squeezed into the damage holes/slits under the confining pressure. Such self-healing capacity can guarantee that the GCL functions properly in some circumstances; for example, holing up to $30 \mathrm{~mm}$ in diameter [74,75]. Figure 7 is a photograph showing the self-healed result of a GCL pierced by a bolt. The self-healing capacity of a GCL liner is commonly assessed using percent swell tests or direct measurements of hydraulic conductivity [76,77]. To assess in a quantitative way, Chai et al. (2016) [26] proposed a concept, the "self-healing ratio" (the area healed by bentonite divided by the total damaged area), and an explicit empirical equation for predicting the self-healing ratio. 


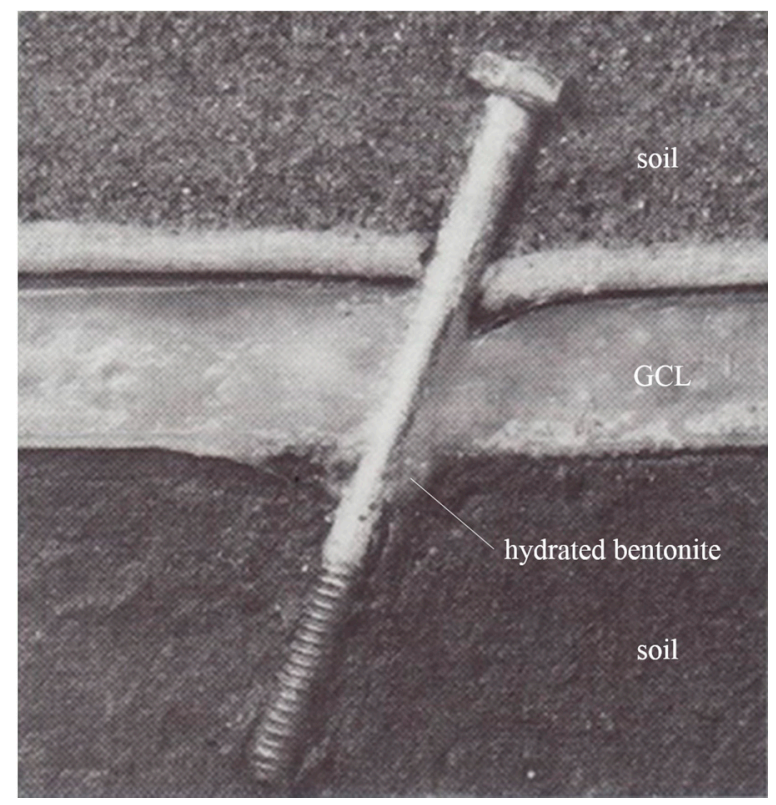

Figure 7. Self-healing of GCL pierced by a bolt (modified from Koerner, 1990) [78].

Extensive laboratory tests have been conducted to investigate the factors that influence the self-healing capacity of GCLs. In general, all of the factors affecting the swelling capacity of bentonite will influence the self-healing ability of GCLs [70]. The swelling amount of bentonite can be influenced by the following factors: (i) internal factors, e.g., bentonite mass, binding method; and (ii) external factors, e.g., permeant solution type, overburden pressure, hydraulic head. The most vital element of bentonite in GCLs is smectite, which is responsible for the swell potential. It has been proven that a higher amount of bentonite in the liner, or a higher content of smectite in bentonite, can contribute to a better self-healing capacity [79,80]. Furthermore, the method of binding the GCL components has a significant influence to self-healing ability, e.g., needle-punched GCLs have better self-healing capacity than stitch-bonded GCLs [75,81].

The hydrated bentonite particles in a defect area can be carried away under huge seepage force $[10,19,21,82,83]$, resulting in the destruction of the self-healing capacity [84]. Overburden stress may affect the self-healing capability in two opposite ways: (i) squeezing the bentonite into damaged holes/slits, thus increasing the capability of self-healing; (ii) constraining the expansion of the bentonite, causing reduction of the self-healing capability. The latter occurs when the overburden stress of the bentonite is greater than the swelling pressure [70]. The type of permeant solution also has a significant impact, and all of the factors affecting the DDL around the bentonite particles will also contribute to a change of self-healing capability $[59,70,85]$.

\subsection{Diffusion}

Diffusion refers to the migration of ions or molecules as a result of their random thermal motion from a higher concentration region to lower concentration region without the transportation of seepage water. For some typical situations, the advective flows are extremely slow and molecular diffusion may be the main mechanism of transporting through the GCL system [86]. The diffusion process of molecules and ions through GCLs can be described by the following equations proposed by Fick (1855) [87]:

$$
\begin{gathered}
J=-D \frac{d C}{d x} \\
\frac{\partial C}{\partial t}=\frac{\partial}{\partial x}\left(D \frac{\partial C}{\partial x}\right)
\end{gathered}
$$


where, $J=$ diffusion flux; $C=$ volume concentration of diffusive substance; $d C / d x, \partial C / \partial x=$ concentration gradient; $d C / d t=$ concentration variation rate with time; and $D=$ diffusion coefficient.

The diffusion coefficient is a critical parameter for evaluating the diffusion capacity of molecules or ions through GCLs. Several apparatus and test methods for the evaluation of the GCL diffusion coefficient have been proposed [88-90]. The test involves placing a contaminant source solution on one side of a GCL specimen and an uncontaminated receptor solution on the other side (see Figure 8). Factors influencing the diffusion coefficient of GCLs have been widely investigated. Lake and Rowe (2000) [86] indicates that the diffusion coefficient has a significant linear correlation with the final bulk GCL void ratio (defined as the void volume divided by the solid volume in GCLs at the end of testing). The diffusion coefficients for different chemical molecules or ions through GCLs can vary a lot. Lake and Rowe (2004) [23] investigated the diffusion of acetone through a GCL under normal conditions. The results indicated the diffusion rate of mass through the GCL for different molecules, from high to low, are: dichloromethane, dichloromethane, benzene, trichloroethylene, toluene. Rowe, et al. (2005) [89] further investigated the diffusion of benzene and concluded that the order, from high to low, is: toluene, ethylbenzene, $\mathrm{m} \& \mathrm{p}$-xylene and o-xylenen.

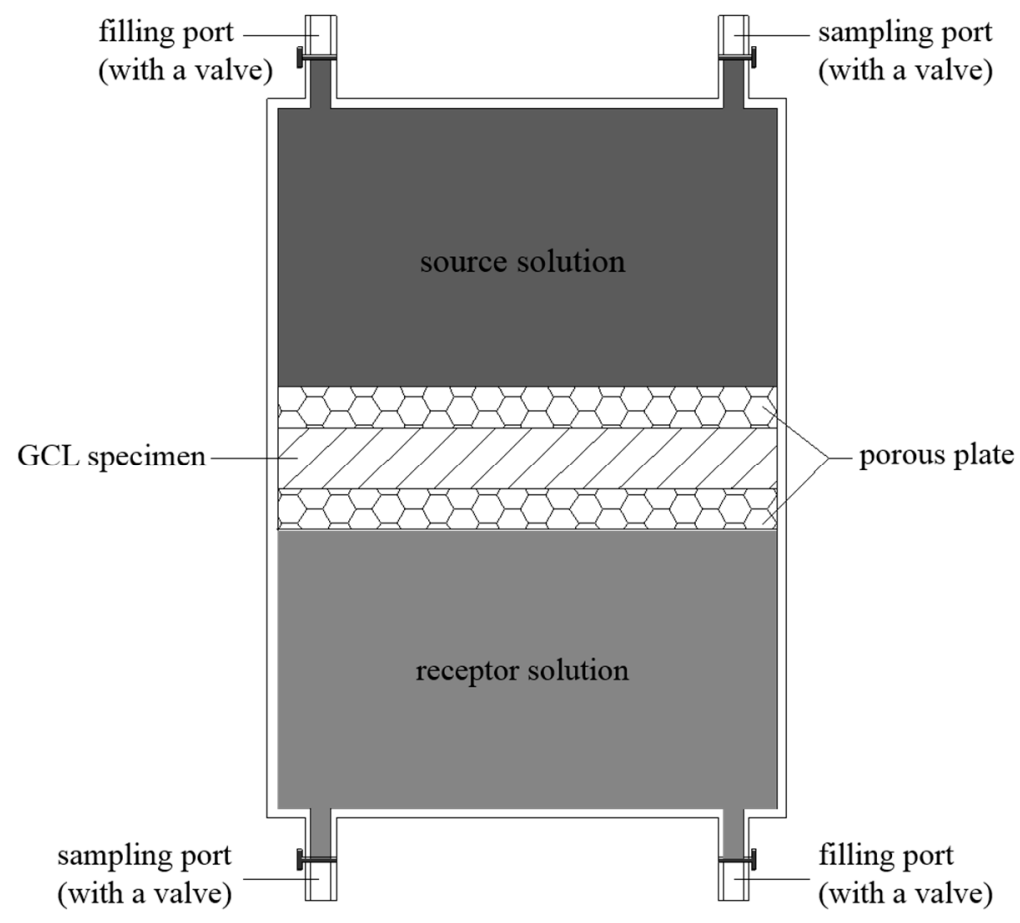

Figure 8. Illustration of diffusion-testing instrument.

The diffusion coefficient can be also significantly influenced by the concentration level of the solute, which is able to modify the microstructure of the sensitive minerals [86]. However, Lange et al. (2009) [91] conducted laboratory tests on metal diffusion through GCLs from four solutions collected from landfill wastes, and found no significant variation of the metal diffusion coefficients. For instance, the diffusion coefficient of $\mathrm{Cu}, \mathrm{Ni}$, Fe and $\mathrm{Cd}$ is within the range of $0.67 \times 10^{-10}$ to $0.98 \times 10^{-10} \mathrm{~m}^{2} / \mathrm{s}$, while $0.80 \times 10^{-10}$ to $1.6 \times 10^{-10}$ for $\mathrm{As}, \mathrm{Al}, \mathrm{Mg}$ and $\mathrm{Sr}$. They also pointed out that some other cations (e.g., $\mathrm{Na}^{+}$) can be sensitive to the solution $\mathrm{pH}$.

The diffusion also depends on temperature, with lower value at a relatively lower temperature [89]. What is noteworthy is that, by contrast with the influence on hydraulic conductivity of GCLs, the type of bentonite contained in GCLs (sodium or calcium) and the ion exchange in bentonite (e.g., from sodium to calcium) both have no obvious influence on the diffusion coefficient of GCLs $[90,92]$. 


\subsection{Gas Migration}

Except for the hydraulic barrier, the objective of GCLs in cover systems should also include the control of leakage of toxic gas from waste and the migration of oxygen into waste. As with the movement of liquid through GCL, gas migration occurs by two means: permeation and diffusion. The driving force for gas permeation is the pressure differentials across the two sides of the liner system, which can result from natural fluctuations in atmospheric pressure, or changes of the temperature or water table $[54,93,94]$. Gas diffusion occurs in response to a concentration gradient of the gas. The molecules move from a high concentration area to a low concentration area.

To prevent gas migration, the pores in bentonite need to be saturated during their lifetime. However, this is difficult to achieve because experience has indicated that the occurrence of unsaturated flow is unavoidable in liner systems [94]. Vangpaisal and Bouazza (2004) [94] conducted a group of gas migration tests on different, partially hydrated GCLs, and the results indicated that gas permeability was closely related to the variation of moisture and volumetric water content. As the gravimetric moisture and volumetric water content increases, the gas migration rate of GCLs decreases accordingly (see Figure 9) [95]. Didier et al. (2000) [96] indicated that the gas permeability was linearly related to the volumetric water content on a linear-log scale. The relationship between the gas diffusion coefficient and the effective diffusion has been investigated by many researchers [97-99], and the results are plotted in Figure 10. It is evident that the diffusion coefficient of gas decreased with the increase of saturation degree. Environmental factors such as straining and wet-dry cycles can induce strain cracks and desiccation cracks in bentonite within GCLs, which provide a preferential flow path, thus accelerating gas permeation through the GCL $[27,94]$.

The structure of GCL can also influence its gas permeability; for example, stich-bonded GCL has a higher gas permeability than needle-punched GCL. GCLs with a poor distribution of needle-punched fibers will have gas permeability up to three orders of magnitude higher than that with uniform distribution [100,101]. Besides, in actual applications, it is not uncommon for some space to exist at the interface of the GM/GCL composite cover, which will inevitably provide a flow path for gas migration [22,33].

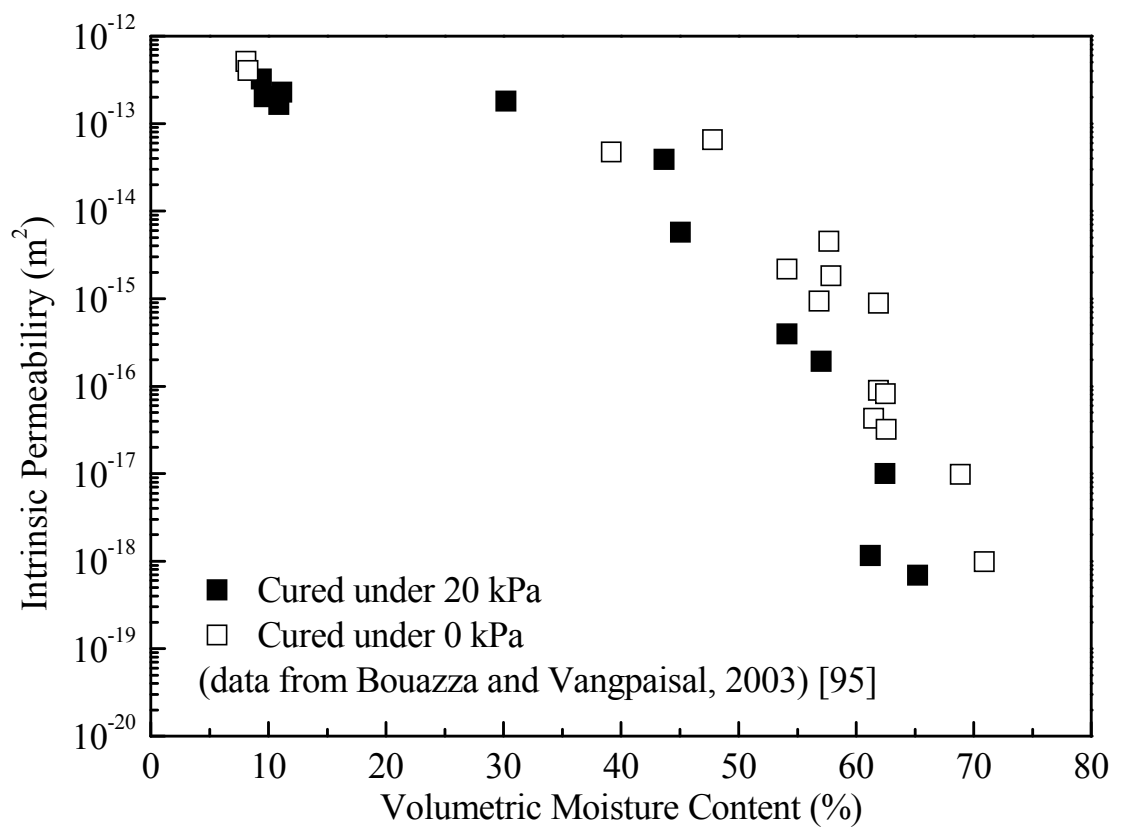

Figure 9. Gas permeability of nitrogen against volumetric moisture content. 


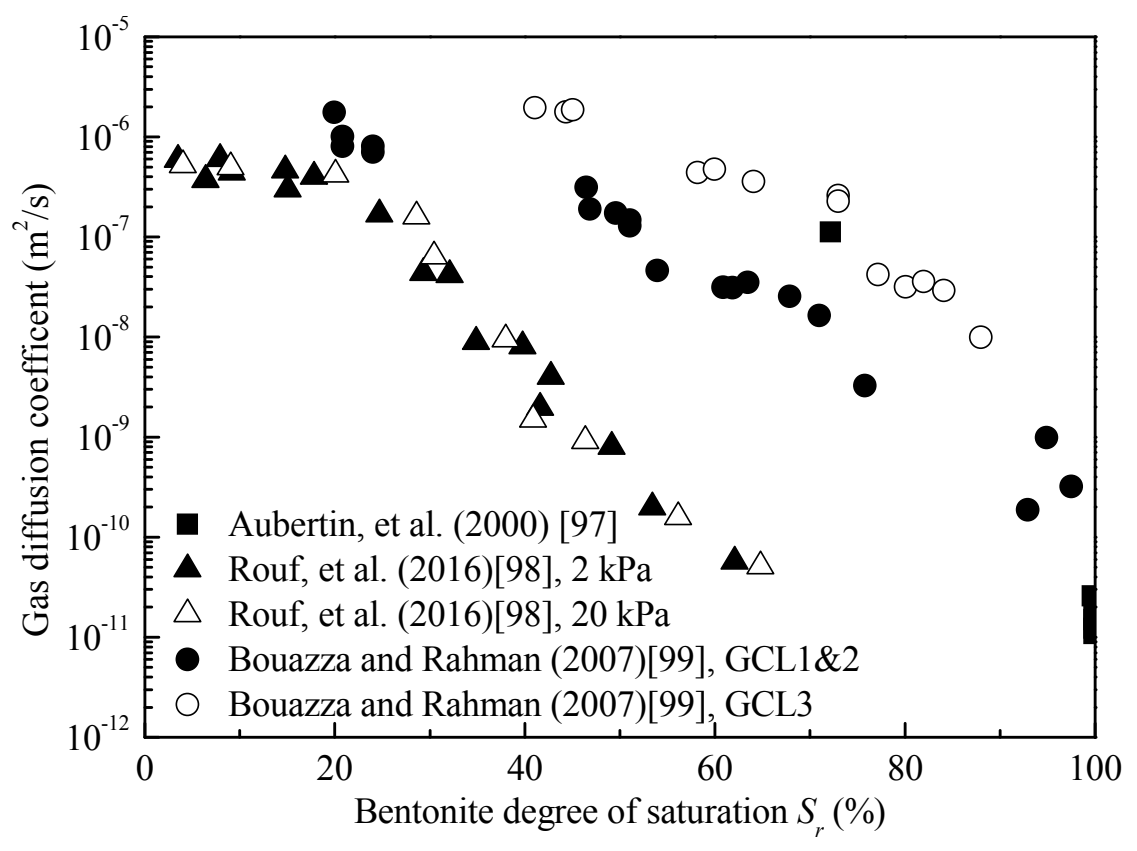

Figure 10. Diffusion coefficient of oxygen against bentonite degree of saturation.

\subsection{Mechanical Behaviour}

Stability is an importation consideration for GCLs which are applied in cover and slope-lining systems of waste landfills. GCLs are commonly expected to suffer from transient shear stress during construction, as well as permanent shear stress in some cases. During the design stage, two aspects of shear strength should be taken into account for stability analysis: (i) the internal shear strength of GCL; (ii) the interface shear strength between GCL and adjacent materials.

\subsubsection{Internal Shear Strength}

The internal shear strength and variables governing the strength for different types of GCLs have been investigated by many researchers using direct shear tests [37,102-108]. These indicate that all of the GCLs exhibit strain-softening characteristics under direct shear. For unreinforced GCLs that are bonded together with a chemical binder (e.g., adhesive-bonded, GM-GCL), since no reinforcement exists in the bentonite the products provide a relatively low resistance to shear force. For reinforced GCLs (e.g., stitch-bonded, and needle-punched GT-GCL), the piercing fibers and the stitch will act as reinforcement materials leading to a significant increase in shear strength $[103,104]$. Typically, owing to the frictional connection of the reinforcing fibers, needle-punched GCL has a higher peak shear strength than other types of GCL $[105,106]$. For each type of GCL, failure occurs at the interface of geotextile and bentonite. The stitch-bonded GCL fails when the stitching lines rip through the geotextile, while the needle-punched GCL fails when reinforcing fibers pull out of the geotextile [105]. In terms of stability, reinforced GCLs are suitable for high-stress application, while unreinforced GCLs are suitable for low-stress applications.

Except for some types of GCLs, the hydration condition, the normal stress and the shear-displacement rate will also contribute to internal shear strength variability [103]. Hydration will lead to an increase in the water content of the bentonite as well as a significant decrease of the internal shear strength. Hydration fluid, hydration time, and normal stress during hydration are the key factors influencing the hydrated shear strength [104]. For needle-punched GCLs, the peak shear strength increases with normal stress, while for stitch-bonded GCLs, it seems to be independent of normal stress. Under a low normal stress, the peak shear strength of reinforced GCLs was observed to increase with the shearing rate $[103,105]$; however, under a high normal stress, the trend will be 
reversed [106]. This is because negative pore water pressures are generated during shearing under low normal stress, while positive pore water pressures are generated under high normal stress.

\subsubsection{Interface Shear Strength}

GCLs are usually laid under the geomembranes (GM) to form a composite liner system in landfills. As a critical factor for stability, the shear strength of the interface between GCL and GM has been widely studied [28,94,109-113]. Compared with GM sheared against normal geotextiles, what makes the GCL-GM interface specific is the presence of extruded bentonite, which can significantly reduce interface friction $[23,24,110]$. Laboratory tests have indicated that the GM-GCL interface has smaller peak shear strength and greater large-displacement strengths than GCL internal shear specimens [112]. The failure modes of a GM-GCL system can transform from interface failure to GCL internal failure as normal stress increases, according to many laboratory tests [102,112,114].

The measured value of the interface shear strength depends on several factors, such as product type, normal stress, hydration fluid, hydration condition, and shear conditions. The product type is determined by the type of geotextiles (woven or non-woven) and the roughness of the geomembranes' surface. For example, a woven geotextiles-geomembrane interface has lower strength than non-woven geotextile interfaces and smooth GM interfaces, because the bentonite is more likely to be in the former [54,110]. The extrusion of bentonite is also relevant to the normal stress applied during shear. A higher normal stress will lead to a greater amount of extrusion and a smaller interface shear strength $[110,115]$. If the products are pre-hydrated, the bentonite will be extruded in the interface more easily than those without predisposal of hydration, and thus will have a lower interface strength [115]. The loading sequence and loading rate also play an important role; for example, GCL/GM products subjected to swelling before loading will have obvious bentonite extrusion, while those subjected to a reverse sequence will exhibit no extrusion in the interface. The amount of extruded bentonite increases as the loading rate increases [116].

\section{Recent Advancement of GCL and Perspectives}

\subsection{Polymer-Treated GCL}

Exposure to inorganic solutions can cause significant degradation of the hydraulic properties of bentonite clay in GCLs. In order to enhance the hydraulic performance and chemical resistance of GCLs, numerous bentonite modification technologies, e.g., adding glycerol carbonate or propylene carbonate, have been developed [117-119]. Recent progress has been made by adding a polyelectrolyte polymer into the bentonite clay.

A polymer is a large molecule, or macromolecule, composed of many repeated sub-units. The application of polymers (macromolecule resin, polymeric fiber) in environmental geotechnics has become more popular in some areas of the world, such as Europe, America and Asia, e.g., Japan. Due to the low hydraulic conductivity and high swelling potential, a macromolecule resin in GCL as a substituted material of bentonite has been explored in Japan. The main chemical composition of the water-swelling polymer is acrylic acid, and its water-absorbing capacity can be from several to several dozen times the value of the bentonite, e.g., $1 \mathrm{~g}$ of polymer material can absorb a few hundred grams or even several kilograms of water. The mechanism of water swelling of the polymer is illustrated in Figure 11. However, the water-swelling capacity of acrylic materials can be impaired when in contact with sea water or other solutions with a high concentration of cations.

Since there are pros and cons to both bentonite and polymer, the new concept of combining bentonite and polymer to form a high-performance anti-seepage liner in GCL has been developed in recent years. The use of polymer for enhancing the mechanical and hydraulic behaviours of clay materials has been well studied [120-123]. However, research on a polymer-treated GCL is still at a preliminary stage, and references are relatively limited. Elhajji et al. (2001) [124] shows that polymers can improve the hydraulic performance of GCL when permeated with low-concentrated 
contaminant. Tests conducted by Ashmawy (2002) [125] indicate that polymer treatment will be more beneficial if the clay is first saturated with water and not directly with the leachate. When low hydraulic conductivity is required in the short term, pre-hydration is more advantageous than polymer treatment. Razakamanantsoa et al. (2012) [126] conducted laboratory test on the different types of polymer-treated GCL, and found different polymer had different effects. For example, cationic polymer can improve the swelling capacity of the bentonite, while anionic polymer enhances the hydraulic behavior of the product. Compared with the untreated variety, both cationic and anionic polymers improve the properties of the bentonite. Scalia et al. (2014) [127] conducted laboratory tests that enabled the bentonite-polymer composite (BPC) to come in contact with aggressive inorganic leachate. The results indicated that BPC had a better long-term anti-seepage performance than the natural bentonite, with low hydraulic conductivity and high swelling capacity. In particular, Yang et al. (2017) $[30,45]$ proposed a SHMP-amended calcium bentonite which has been found to be promising in contaminant-containment applications due to its superior resistance to DDL compression caused by heavy metal and salt exposure. All of this research shows that the present polymer-treated technology has great potential in future GCL applications.

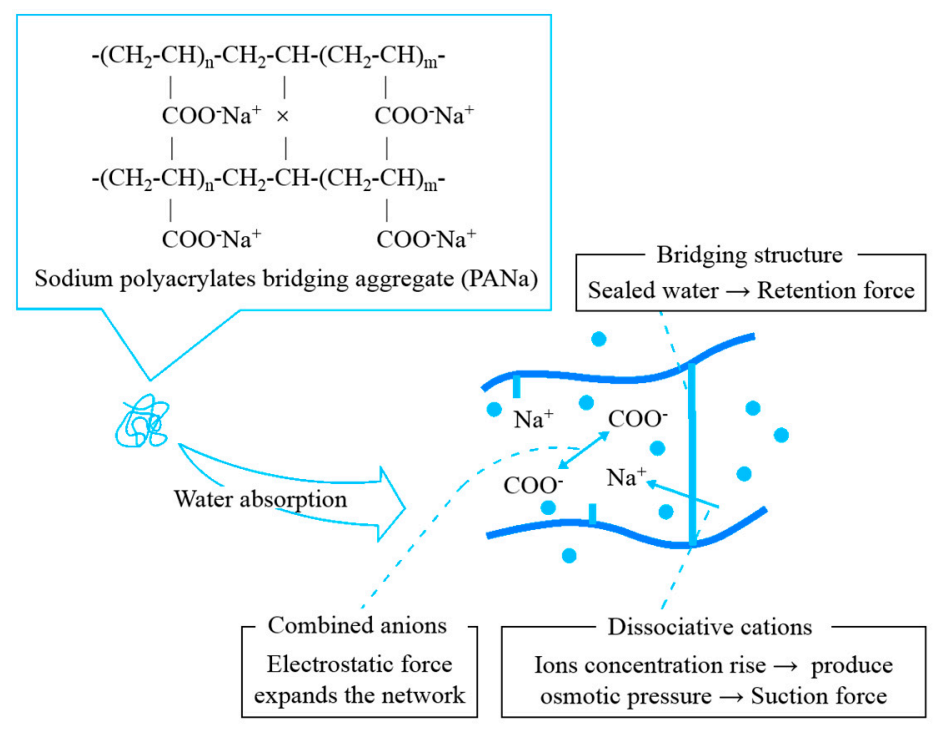

Figure 11. Mechanism of water swelling of polymer (modified from Fujida, 2011) [128].

\subsection{Perspectives for Further Study}

Polymer chemistry has experienced great development in recent years, and varieties of new polymer materials have been developed. Bentonite is a natural product whose components can vary from region to region. The diversity of both polymers and bentonites provides great possibilities for the future exploration of a polymer-bentonite composite that provides a high-performance GCL. For further study, the microstructure of the polymer-treated bentonite needs to be investigated in comprehensive and systematic ways. The microstructure of the polymer-bentonite composite created by using the technology of free-radical polymerization, with its relationship to the macro behaviors of PBC (e.g., hydraulic conductivity, water-swelling capacity, chemical compatibility, self-healing) should be further investigated.

\section{Conclusions}

This paper provides a systematic summary of research on geosynthetic clay liners over the past decades, and the following conclusions can be drawn:

(a) Research on geosynthetic clay liners has experienced rapid growth over the past few decades. Numerous laboratory investigations and field tests have been undertaken to examine the 
performance of geosynthetic clay liners, such as their hydraulic conductivity and chemical compatibility, water-swelling and self-healing capacity, diffusion, gas migration, and shear strength. These properties are found to be affected by a variety of factors, e.g., structural types, permeant solution, hydration condition, confining pressure, environmental factors (temperature, hydraulic head, etc.), which can vary from case to case. It is of great importance to assess the properties of GCL on a site-specific basis.

(b) With the wide use of GCLs in landfills and other geotechnical applications, more problems concerned with complicated environments, such as moisture-cycles, freeze-thaw cycles, thermal cycles, long-term exposure to solar radiation, GCL-lined slopes, can be encountered. Such particular environments may significantly influence the long-term hydraulic performance and durability of GCLs. Although primary studies on the impact of these factors can be found in some publications, the mechanism by which complicated conditions influence the physical and chemical properties of GCL components needs to be further investigated.

(c) Polymer-treated technology has shown great potential for future GCL applications. The expansion capacity of bentonite in GCLs decreases when permeating aggressive leakages with high cation concentration. The addition of superabsorbent polymers, which have much higher resistance to aggressive leakages, can make up for the deficiency of bentonite and greatly improve hydraulic performance and self-healing capacity. Research on polymer-treated GCLs is still in its preliminary stages. Further study needs to be conducted on the microstructure of polymer-bentonite composite created by using the technology of free radical polymerization as well as on the macro behaviors of polymer-bentonite composites (e.g., hydraulic conductivity, water-swelling capacity, chemical compatibility, diffusion, gas migration, and shear strength).

Acknowledgments: This research work was funded by the National Nature Science Foundation of China (NSFC) (Grant No. 51578333). This financial support is gratefully acknowledged.

Author Contributions: This paper represents a result of the collaborative teamwork. Huai-Na Wu and De-Jun Kong collected the data sources, De-Jun Kong wrote the manuscript, Jin-Chun Chai and Arul Arulrajah provided constructive suggestions for the manuscript. The four authors contributed equally to this work.

Conflicts of Interest: The authors declare no conflict of interest.

\section{References}

1. Shen, S.L.; Wang, Z.F.; Horpibulsuk, S.; Kim, Y.H. Jet-Grouting with a newly developed technology: The Twin-Jet Method. Eng. Geol. 2013, 152, 87-95. [CrossRef]

2. Shen, S.L.; Wang, Z.F.; Sun, W.J.; Wang, L.B.; Horpibulsuk, S. A field trial of horizontal jet grouting using the composite-pipe method in the soft deposit of Shanghai. Tunn. Undergr. Space Technol. 2013, 35, 142-151. [CrossRef]

3. Shen, S.L.; Ma, L.; Xu, Y.S.; Yin, Z.Y. Interpretation of increased deformation rate in aquifer IV due to groundwater pumping in Shanghai. Can. Geotech. J. 2013, 50, 1129-1142. [CrossRef]

4. Wu, Y.X.; Shen, S.L.; Xu, Y.S.; Yin, Z.Y. Characteristics of groundwater seepage with cutoff wall in gravel aquifer. I: Field observations. Can. Geotech. J. 2015, 52, 1526-1538. [CrossRef]

5. Wu, Y.X.; Shen, S.L.; Yin, Z.Y.; Xu, Y.S. Characteristics of groundwater seepage with cutoff wall in gravel aquifer. II: Numerical analysis. Can. Geotech. J. 2015, 52, 1539-1549. [CrossRef]

6. Xu, Y.S.; Ma, L.; Shen, S.L.; Sun, W.J. Evaluation of land subsidence by considering underground structures penetrated into aquifers in Shanghai. Hydrogeol. J. 2012, 20, 1623-1634. [CrossRef]

7. Xu, Y.S.; Shen, S.L.; Ma, L.; Sun, W.J.; Yin, Z.Y. Evaluation of the blocking effect of retaining walls on groundwater seepage in aquifers with different insertion depths. Eng. Geol. 2014, 183, 254-264. [CrossRef]

8. Ma, L.; Xu, Y.S.; Shen, S.L.; Sun, W.J. Evaluation of the hydraulic conductivity of aquifer with piles. Hydrogeol. J. 2014, 22, 371-382. [CrossRef]

9. Shen, S.L.; Wang, Z.F.; Cheng, W.C. Estimation of lateral displacement induced by jet grouting in clayey soils. Geotechnique 2017, 67, 621-630. [CrossRef] 
10. Shen, S.L.; Wu, Y.X.; Misra, A. Calculation of head difference at two sides of a cut-off barrier during excavation dewatering. Comput. Geotech. 2017, 91, 192-202. [CrossRef]

11. Daniel, D.E. Geotechnical Practice for Waste Disposal; Springer: Boston, MA, USA, 1993.

12. Du, Y.J.; Hayashi, S. A study on sorption properties of $\mathrm{Cd}^{2+}$ on Ariake clay for evaluating its potential use as a landfill barrier material. Appl. Clay Sci. 2006, 32, 14-24. [CrossRef]

13. Shackelford, C.D.; Meier, A.; Sample-Lord, K. Limiting membrane and diffusion behavior of a geosynthetic clay liner. Geotext. Geomembr. 2016, 44, 707-718. [CrossRef]

14. Liu, Y.; Bouazza, A.; Gates, W.P.; Rowe, R.K. Hydraulic performance of geosynthetic clay liners to sulfuric acid solutions. Geotext. Geomembr. 2015, 43, 14-23. [CrossRef]

15. Shen, S.L.; Wang, Z.F.; Yang, J.; Ho, C.E. Generalized approach for prediction of jet grout column diameter. J. Geotech. Geoenviron. Eng. 2013, 139, 2060-2069. [CrossRef]

16. Shen, S.L.; Wu, H.N.; Cui, Y.J.; Yin, Z.Y. Long-term settlement behavior of the metro tunnel in Shanghai. Tunn. Undergr. Space Technol. 2014, 40, 309-323. [CrossRef]

17. Tan, Y.; Lu, Y. Forensic diagnosis of a leaking accident during excavation. J. Perform. Constr. Facil. ASCE 2017, 31, 4017061. [CrossRef]

18. Tan, Y.; Lu, Y. Why excavation of a small air shaft caused excessively large displacements: Forensic investigation. J. Perform. Constr. Facil. ASCE 2017, 31, 4016083. [CrossRef]

19. Wu, H.N.; Shen, S.L.; Liao, S.M.; Yin, Z.Y. Longitudinal structural modelling of shield tunnels considering shearing dislocation between segmental rings. Tunn. Undergr. Space Technol. 2015, 50, 317-323. [CrossRef]

20. Wu, H.N.; Shen, S.L.; Yang, J. Identification of tunnel settlement caused by land subsidence in soft deposit of Shanghai. J. Perform. Constr. Facil. ASCE 2017, 31, 4017092. [CrossRef]

21. Shen, S.L.; Xu, Y.S. Numerical evaluation of land subsidence induced by groundwater pumping in Shanghai. Can. Geotech. J. 2011, 48, 1378-1392. [CrossRef]

22. Shackelford, C.D.; Benson, C.H.; Katsumi, T.; Edil, T.B.; Lin, L. Evaluating the hydraulic conductivity of GCLs permeated with non-standard liquids. Geotext. Geomembr. 2000, 18, 133-161. [CrossRef]

23. Lake, C.B.; Rowe, R.K. Volatile organic compound diffusion and sorption coefficients for a needle-punched GCL. Geosynth. Int. 2004, 11, 257-272. [CrossRef]

24. Bouazza, A.; Vangpaisal, T.; Jefferis, S. Effect of wet-dry cycles and cation exchange on gas permeability of geosynthetic clay liners. J. Geotech. Geoenviron. Eng. 2006, 132, 1011-1018. [CrossRef]

25. Fox, P.J.; Ross, J.D. Relationship between NP GCL internal and HDPE GMX/NP GCL interface shear strengths. J. Geotech. Geoenviron. Eng. 2011, 137, 743-753. [CrossRef]

26. Chai, J.C.; Sari, K.; Shen, S.L.; Cai, Y.Q. Predicting self-healing ratio of GCL with a damage hole. Geotext. Geomembr. 2016, 44, 761-769. [CrossRef]

27. Zhang, N.; Shen, S.L.; Wu, H.N.; Chai, J.C. Evaluation of effect of basal geotextile reinforcement under embankment loading on soft marine deposits. Geotext. Geomembr. 2015, 43, 506-514. [CrossRef]

28. Du, Y.J.; Hayashi, S.; Shen, S.L. Contaminant mitigating performance of Chinese standard municipal solid waste landfill liner systems. Geotext. Geomembr. 2009, 27, 232-239. [CrossRef]

29. Yin, Z.Y.; Xu, Q.; Yu, C. Elastic-Viscoplastic modeling for natural soft clays considering nonlinear creep. Int. J. Geomech. 2014, 14, A6014001. [CrossRef]

30. Yang, Y.L.; Reddy, K.R.; Du, Y.J.; Fan, R.D. SHMP amended calcium bentonite for slurry trench cutoff walls: Workability and microstructure characteristics. Can. Geotech. J. 2017. [CrossRef]

31. Yang, Y.L.; Reddy, K.R.; Du, Y.J.; Fan, R.D. Short-term hydraulic conductivity and consolidation properties of soil-bentonite backfills exposed to CCR-impacted groundwater. ASCE J. Geotech. Geoenviron. Eng. 2017. accepted.

32. Du, Y.J.; Wei, M.L.; Reddy, K.R.; Liu, Z.P.; Jin, F. Effect of acid rain pH on leaching behavior of cement stabilized lead-contaminated soil. J. Hazard. Mater. 2014, 271, 131-140. [CrossRef] [PubMed]

33. Estornell, P.; Daniel, D.E. Hydraulic Conductivity of Three Geosynthetic Clay Liners. J. Geotech. Eng. 1992, 118, 1592-1606. [CrossRef]

34. Koerner, R.M. Designing with Geosynthetics, 5th ed.; Prentice Hall Book Co.: Upper Saddle River, NJ, USA, 2005.

35. Yin, Z.Y.; Chang, C.S.; Karstunen, M.; Hicher, P.Y. An anisotropic elastic viscoplastic model for soft clays. Int. J. Solids Struct. 2010, 47, 665-677. [CrossRef]

36. Yin, Z.Y.; Hattab, M.; Hicher, P.Y. Multiscale modeling of a sensitive marine clay. Int. J. Numer. Anal. Methods Geomech. 2011, 35, 1682-1702. [CrossRef] 
37. Yin, Z.Y.; Xu, Q.; Hicher, P.Y. A simple critical state based double-yield-surface model for clay behavior under complex loading. Acta Geotech. 2013, 8, 509-523. [CrossRef]

38. Yin, Z.Y.; Zhao, J.; Hicher, P.Y. A micromechanics-based model for sand-silt mixtures. Int. J. Solids Struct. 2014, 51, 1350-1363. [CrossRef]

39. Yin, Z.Y.; Yin, J.H.; Huang, H.W. Rate-dependent and long-term yield stress and strength of soft Wenzhou marine clay: Experiments and modeling. Mar. Georesour. Geotechnol. 2015, 33, 79-91. [CrossRef]

40. Jin, Y.F.; Yin, Z.Y.; Shen, S.L.; Hicher, P.Y. Selection of sand models and identification of parameters using an enhanced genetic algorithm. Int. J. Numer. Anal. Methods Geomech. 2016, 40, 1219-1240. [CrossRef]

41. Jin, Y.F.; Yin, Z.Y.; Shen, S.L.; Hicher, P.Y. Investigation into MOGA for identifying parameters of a critical-state-based sand model and parameters correlation by factor analysis. Acta Geotech. 2016, 11, 1131-1145. [CrossRef]

42. Jin, Y.F.; Wu, Z.X.; Yin, Z.Y.; Shen, J.S. Estimation of critical state-related formula in advanced constitutive modeling of granular material. Acta Geotech. 2017. [CrossRef]

43. Du, Y.J.; Fan, R.D.; Liu, S.Y.; Reddy, K.R.; Jin, F. Workability, compressibility and hydraulic conductivity of zeolite-amended clayey soil/calcium-bentonite backfills for slurry-trench cutoff walls. Eng. Geol. 2015, 195, 258-268. [CrossRef]

44. Du, Y.J.; Fan, R.D.; Reddy, K.R.; Liu, S.Y.; Yang, Y.L. Impacts of presence of lead contamination in clayey soil-calcium bentonite cutoff wall backfills. Appl. Clay Sci. 2015, 108, 111-122. [CrossRef]

45. Yang, Y.L.; Du, Y.J.; Reddy, K.R.; Fan, R.D. Phosphate-amended sand/Ca-bentonite mixtures as slurry trench wall backfills: Assessment of workability, compressibility and hydraulic conductivity. Appl. Clay Sci. 2017, 142, 120-127. [CrossRef]

46. Shen, S.L.; Cui, Q.L.; Ho, E.C.; Xu, Y.S. Ground response to multiple parallel microtunneling operations in cemented silty clay and sand. J. Geotech. Geoenviron. Eng. 2016, 142, 1-11. [CrossRef]

47. Wikipedia. Available online: https://en.wikipedia.org/wiki/Montmorillonite (accessed on 9 November 2017).

48. Ruedrich, J.; Bartelsen, T.; Dohrmann, R.; Siegesmund, S. Moisture expansion as a deterioration factor for sandstone used in buildings. Environ. Earth Sci. 2011, 63, 1545-1564. [CrossRef]

49. Mitchell, J.K. Fundamentals of Soil Behavior, 3rd ed.; Wiley: Hoboken, NJ, USA, 2005.

50. Du, Y.J.; Jiang, N.J.; Liu, S.Y.; Jin, F.; Singh, D.N.; Pulppara, A. Engineering properties and microstructural characteristics of cement solidified zinc-contaminated kaolin clay. Can. Geotech. J. 2014, 51, 289-302. [CrossRef]

51. Du, Y.J.; Horpibulsuk, S.; Wei, M.L.; Martin, L. Modeling compression behavior of cement treated zinc contaminated clayey soils. Soils Found. 2014, 54, 1018-1026. [CrossRef]

52. Bolt, G.H. Physico-Chemical Analysis of the Compressibility of Pure Clays. Géotechnique 1956, 6, 86-93. [CrossRef]

53. Jo, H.Y.; Katsumi, T.; Benson, C.H.; Edil, T.B. Hydraulic Conductivity and Swelling of Nonprehydrated GCLs Permeated with Single-Species Salt Solutions. J. Geotech. Geoenviron. Eng. 2001, 127, 557-567. [CrossRef]

54. Bouazza, A. Geosynthetic clay liners. Geotext. Geomembr. 2002, 20, 3-17. [CrossRef]

55. Benson, C.H. Impact of subgrade water content on cation exchange and hydraulic conductivity of geosynthetic clay liners in composite barriers. In Coupled Phenomena in Environmental Geotechnics; CRC Press: Boca Raton, FL, USA, 2013; pp. 79-84.

56. Rowe, R.K.; Brachman, R.W.I.; Take, W.A.; Rentz, A.; Ashe, L.E. Field and laboratory observations of down-slope bentonite migration in exposed composite liners. Geotext. Geomembr. 2016, 44, 686-706. [CrossRef]

57. Benson, C.H.; Thorstad, P.A.; Jo, H.Y.; Rock, S.A. Hydraulic performance of geosynthetic clay liners in a landfill final cover. J. Geotech. Geoenviron. Eng. 2007, 133, 814-827. [CrossRef]

58. Benson, C.H.; Kucukkirca, I.E.; Scalia, J. Properties of geosynthetics exhumed from a final cover at a solid waste landfill. Geotext. Geomembr. 2010, 28, 536-546. [CrossRef]

59. Egloffstein, T.A. Natural bentonites-influence of the ion exchange and partial desiccation on permeability and self-healing capacity of bentonites used in GCLs. Geotext. Geomembr. 2001, 19, 427-444. [CrossRef]

60. Setz, M.C.; Tian, K.; Benson, C.H.; Bradshaw, S.L. Effect of ammonium on the hydraulic conductivity of geosynthetic clay liners. Geotext. Geomembr. 2017. [CrossRef]

61. Shackelford, C.D.; Sevick, G.W.; Eykholt, G.R. Hydraulic conductivity of geosynthetic clay liners to tailings impoundment solutions. Geotext. Geomembr. 2010, 28, 149-162. [CrossRef] 
62. Jo, H.Y.; Benson, C.H.; Shackelford, C.D.; Lee, J.-M.; Edil, T.B. Long-Term Hydraulic Conductivity of a Geosynthetic Clay Liner Permeated with Inorganic Salt Solutions. J. Geotech. Geoenviron. Eng. 2005, 131, 405-417. [CrossRef]

63. Vasko, S.; Jo, H.; Benson, C.; Edil, T.; Kataumi, T. Hydraulic conductivity of partially prehydrated geosynthetic clay liners permeated with aqueous calcium chlorides solution. In Proceedings of the Geosynthetics Conference, Oregon, OR, USA, 12-14 February 2001.

64. Rosin-Paumier, S.; Touze-Foltz, N. Hydraulic and chemical evolution of GCLs during filter press and oedopermeametric tests performed with real leachate. Geotext. Geomembr. 2012, 33, 15-24. [CrossRef]

65. Shen, S.L.; Wang, J.P.; Wu, H.N.; Xu, Y.S.; Ye, G.L.; Yin, Z.Y. Evaluation of hydraulic conductivity for both marine and deltaic deposit based on piezocone test. Ocean Eng. 2015, 110, 174-182. [CrossRef]

66. Bouazza, A.; Singh, R.M.; Rowe, R.K.; Gassner, F. Heat and moisture migration in a geomembrane-GCL composite liner subjected to high temperatures and low vertical stresses. Geotext. Geomembr. 2014, 42, 555-563. [CrossRef]

67. Bouazza, A.; Gates, W.P. Overview of performance compatibility issues of GCLs with respect to leachates of extreme chemistry. Geosynth. Int. 2014, 21, 151-167. [CrossRef]

68. Hornsey, W.P.; Scheirs, J.; Gates, W.P.; Bouazza, A. The impact of mining solutions/liquors on geosynthetics. Geotext. Geomembr. 2010, 28, 191-198. [CrossRef]

69. Fox, P.J.; Triplett, E.J.; Kim, R.H.; Olsta, J.T. Field Study of Installation Damage for Geosynthetic Clay Liners. Geosynth. Int. 1998, 5, 491-520. [CrossRef]

70. Sari, K.; Chai, J.C. Self-healing capacity of geosynthetic clay liners and influencing factors. Geotext. Geomembr. 2013, 41, 64-71. [CrossRef]

71. Rowe, R.K.; Orsini, C. Effect of GCL and subgrade type on internal erosion in GCLs under high gradients. Geotext. Geomembr. 2003, 21, 1-24. [CrossRef]

72. Take, W.A.; Brachman, R.W.I.; Rowe, R.K. Observations of bentonite erosion from solar-driven moisture migration in GCLs covered only by a black geomembrane. Geosynth. Int. 2015, 22, 78-92. [CrossRef]

73. Camillis, M.D.; Emidio, G.D.; Bezuijen, A.; Verástegui-Flores, R.D. Hydraulic conductivity and swelling ability of a polymer modified bentonite subjected to wet-dry cycles in seawater. Geotext. Geomembr. 2016, 44, 739-747. [CrossRef]

74. Mazzieri, F.; Pasqualini, E. Permeability of Damaged Geosynthetic Clay Liners. Geosynth. Int. 2000, 7, 101-118. [CrossRef]

75. Babu, G.L.S.; Sporer, H.; Zanzinger, H.; Gartung, E. Self-healing properties of geosynthetic clay liners. Geosynth. Int. 2001, 8, 461-470. [CrossRef]

76. Shan, S.; Daniel, D.E. Results of laboratory tests on a geotextile/bentonite liner material. In Proceedings of the Geosynthetics Conference, Atlanta, GA, USA, 26-28 February 1991.

77. Rowe, R.K.; Lake, C.B. Geosynthetic clay liner research, design and applications. In Proceedings of the 7th International Waste Management and Landfill Symposium, Cagliari, Italy, 4-8 October 1999.

78. Koerner, R.M. Design with Geosynthetics, 2nd ed.; Prentice Hall: Englewood Cliffs, NJ, USA, 1990.

79. Rowe, R.K.; Li, T.A. Preliminary study of the bentonite self-healing of slits in a GCL upon full hydration. In Proceedings of the Geo-Chicago, Chicago, IL, USA, 14-18 August 2016.

80. Ören, A.H.; Akar, R.Ç. Swelling and hydraulic conductivity of bentonites permeated with landfill leachates. Appl. Clay Sci. 2017, 142, 81-89. [CrossRef]

81. Parastar, F.; Hejazi, S.M.; Sheikhzadeh, M.; Alirezazadeh, A. A parametric study on hydraulic conductivity and self-healing properties of geotextile clay liners used in landfills. J. Environ. Manag. 2017, 202 (Pt 1), $29-37$. [CrossRef] [PubMed]

82. Wu, Y.X.; Shen, S.L.; Yuan, D.J. Characteristics of dewatering induced drawdown curve under barrier effect of retaining wall in aquifer. J. Hydrol. 2016, 539, 554-566. [CrossRef]

83. Wu, Y.X.; Shen, J.S.; Cheng, W.C.; Hino, T. Semi-analytical solution to pumping test data with barrier, wellbore storage, and partial penetration effects. Eng. Geol. 2017, 226, 44-51. [CrossRef]

84. Didier, G.; Al Nassar, M.; Plagne, V.; Cazaux, C. Evaluation of Self-healing ability of geosynthetic clay liners. In Proceedings of the ISRM International Symposium, Melbourne, Australia, 19-24 November 2000.

85. Yang, Y.L.; Du, Y.J.; Reddy, K.R.; Fan, R.D. Compatibility of Phosphate-Amended Ca-Bentonite Soil Backfill with Groundwater Impacted by Coal Ash Leachate. Geotech. Spec. Publ. 2017, 190-199. [CrossRef] 
86. Lake, C.B.; Rowe, R.K. Diffusion of sodium and chloride through geosynthetic clay liners. Geotext. Geomembr. 2000, 18, 103-131. [CrossRef]

87. Fick, A. Ueber diffusion. Ann. Der Phys. 1855, 170, 59-86. [CrossRef]

88. Rowe, R.K.; Lake, C.B.; Petrov, R.J. Apparatus and procedures for accessing inorganic diffusion coefficient for geosynthetic clay liners. Geotech. Test. J. 2000, 23, 206-214.

89. Rowe, R.K.; Asce, F.; Mukunoki, T.; Sangam, H.P. BTEX diffusion and sorption for a geosynthetic clay liner at two temperatures. J. Geotech. Geoenviron. Eng. 2005, 131, 1211-1221. [CrossRef]

90. Paumier, S.; Touzefoltz, N.; Mazeas, L.; Guenne, A. Quantification of volatile organic compounds diffusion for virgin geosynthetic clay liners and for a GCL after contact with a synthetic leachate. J. Geotech. Geoenviron. Eng. 2011, 137, 1039-1046. [CrossRef]

91. Lange, K.; Rowe, R.K.; Jamieson, H. Diffusion of metals in geosynthetic clay liners. Geosynth. Int. 2009, 16, 11-27. [CrossRef]

92. Mendes, M.J.A.; Touze-Foltz, N.; Gardoni, M.; Ahari, M.; Mazeas, L. Quantification of diffusion of phenolic compounds in virgin GCL and in GCL after contact with a synthetic leachate. Geotext. Geomembr. 2013, 38, 16-25. [CrossRef]

93. Zanzinger, H.; Koerner, R.M.; Gartung, E. Clay Geosynthetic Barriers; CRC Press: Boca Raton, FL, USA, 2002.

94. Vangpaisal, T.; Bouazza, A. Gas permeability of partially hydrated geosynthetic clay liners. J. Geotech. Geoenviron. Eng. 2004, 130, 93-102. [CrossRef]

95. Bouazza, A.; Vangpaisal, T. An apparatus to measure gas permeability of geosynthetic clay liners. Geotext. Geomembr. 2003, 21, 85-101. [CrossRef]

96. Didier, G.; Bouazza, A.; Cazaux, D. Gas permeability of geosynthetic clay liners. Geotext. Geomembr. 2000, 18, 235-250. [CrossRef]

97. Aubertin, M.; Aachib, M.; Authier, K. Evaluation of diffusive gas flux through covers with a GCL. Geotext. Geomembr. 2000, 18, 215-233. [CrossRef]

98. Rouf, M.A.; Bouazza, A.; Rao, M.S.; Gates, W.P.; Rowe, R.K. Gas flow unified measurement system for sequential measurement of gas diffusion and gas permeability of partially hydrated geosynthetic clay liners. Can. Geotech. J. 2016, 53, 1000-1012. [CrossRef]

99. Bouazza, A.; Rahman, F. Oxygen diffusion through partially hydrated geosynthetic clay liners. Géotechnique 2007, 57, 767-772. [CrossRef]

100. Bouazza, A.; Vangpaisal, T. Gas advective flux of partially saturated geosynthetic clay liners. In Proceedings of the Geo-Denver, Denver, CO, USA, 5-8 August 2000.

101. Bouazza, A.; Vangpaisal, T. Gas permeability of GCLs, effect of poor distribution of needle-punched fibers. Geosynth. Int. 2007, 14, 248-252. [CrossRef]

102. Gilbert, R.B.; Fernandez, F.; Horsfield, D.W. Shear strength of reinforced geosynthetic clay liner. J. Geotech. Geoenviron. 1996, 122, 259-266. [CrossRef]

103. Gilbert, R.B.; Scranton, H.B.; Daniel, D.E. Shear strength testing for geosynthetic clay liners. In Proceedings of the Symposium on Testing and Acceptance Criteria for Geosynthetic Clay Liners, Atlanta, GA, USA, 29 January 1996.

104. Fox, P.J.; Chiu, P. Internal and interface shear strengths of unreinforced and needle-punched geosynthetic clay liners. Geosynth. Int. 2004, 11, 176-199.

105. Fox, P.J.; Rowland, M.G.; Scheithe, J.R. Internal shear strength of three geosynthetic clay liners. J. Geotech. Geoenviron. Eng. 1998, 124, 933-944. [CrossRef]

106. Zornberg, J.G.; Mccartney, J.S. Analysis of a large database of GCL internal shear strength results. J. Geotech. Geoenviron. Eng. 2005, 131, 367-380. [CrossRef]

107. Eid, H.T.; Stark, T.D. Shear Behavior of an Unreinforced Geosynthetic Clay Liner. Geosynth. Int. 1997, 4, 645-659. [CrossRef]

108. Yin, Z.Y.; Chang, C.S.; Hicher, P.Y. Micromechanical modelling for effect of inherent anisotropy on cyclic behaviour of sand. Int. J. Solids Struct. 2010, 47, 1933-1951. [CrossRef]

109. Stark, T.D.; Eid, H.T. Shear behavior of reinforced geosynthetic clay liners. Geosynth. Int. 1996, 3, 771-786. [CrossRef]

110. Triplett, E.J.; Fox, P.J. Shear strength of HDPE geomembrane/geosynthetic clay liner interfaces. J. Geotech. Geoenviron. Eng. 2001, 127, 543-552. [CrossRef] 
111. Bergado, D.T.; Ramana, G.V.; Sia, H.I.; Varun, V. Evaluation of interface shear strength of composite liner system and stability analysis for a landfill lining system in Thailand. Geotext. Geomembr. 2006, 24, 371-393. [CrossRef]

112. Fox, P.J.; Kim, R.H. Effect of progressive failure on measured shear strength of geomembrane/GCL interface. J. Geotech. Geoenviron. Eng. 2008, 134, 459-469. [CrossRef]

113. Mccartney, J.S.; Zornberg, J.G. Analysis of a Large Database of GCL-Geomembrane Interface Shear Strength Results. J. Geotech. Geoenviron. Eng. 2009, 135, 209-223. [CrossRef]

114. Byrne, R.J. Design issues with strain-softening interfaces in landfill liners. In Proceedings of the Waste Technology, Charleston, SC, USA, 3-5 October 1994.

115. Vukelić, A.; Szavits-Nossan, A.; Kvasnička, P. The influence of bentonite extrusion on shear strength of GCL/geomembrane interface. Geotext. Geomembr. 2008, 26, 82-90. [CrossRef]

116. Chen, Y.M.; Lin, W.A.; Zhan, T.L.T. Investigation of mechanisms of bentonite extrusion from GCL and related effects on the shear strength of GCL/GM interfaces. Geotext. Geomembr. 2010, 28, 63-71. [CrossRef]

117. Fehervari, A.; Gates, W.P.; Patti, A.F.; Turney, T.W.; Bouazza, A.; Rowe, R.K. Potential hydraulic barrier performance of cyclic organic carbonate modified bentonite complexes against hyper-salinity. Geotext. Geomembr. 2016, 44, 748-760. [CrossRef]

118. Bohnhoff, G.L.; Shackelford, C.; Malusis, M.; Scalia, J.; Bension, C.; Edil, T.; Di Emidio, G.; Katsumi, T.; Mazzieri, F. Novel bentonites for containment barrier applications. In Proceedings of the 18th International Conference on Soil Mechanics and Geotechnical Engineering, Pairs, France, 2-6 September 2013.

119. Mazzieri, F.; Emidio, G.D.; Fratalocchi, E.; Sante, M.D.; Pasqualini, E. Permeation of two GCLs with an acidic metal-rich synthetic leachate. Geotext. Geomembr. 2013, 40,1-11. [CrossRef]

120. Green, V.S.; Stott, D.E.; Norton, L.D.; Graveel, J.G. Polyacrylamide molecular weight and charge effects on infiltration under simulated rainfall. SSSAJ 2000, 64, 1786-1791. [CrossRef]

121. Deng, Y.; Dixon, J.B.; White, G.N.; Loeppert, R.H.; Juo, A.S.R. Bonding between polyacrylamide and smectite. Colloid Surface A 2006, 281, 82-91. [CrossRef]

122. Razakamanantsoa, A.R.; Barast, G.; Djeran-Maigre, I.; Couradin, A.; Didier, G. Hydraulic performance of bentonite soil mixture reinforced by polymer in contact of different fluids. In Proceedings of the Journées Nationales de Géotechnique et de Géologiedel'Ingénieur, Nantes, France, 18-20 June 2008.

123. Didier, G.; Comeaga, L. Influence of initial hydration conditions on GCL leachate permeability. In Proceedings of the Symposium on Testing and Acceptance Criteria for Geosynthetic Clay Liners, Atlanta, GA, USA, 29 January 1996.

124. Elhajji, D.; Ashmawy, A.K.; Darlington, J.; Sotelo, N. Effect of inorganic leachate on polymer treated GCL material. In Proceedings of the Geosynthetics, Portland, OR, USA, 12-14 January 2001.

125. Ashmawy, A.K.; Elhajji, D.; Sotelo, N.; Muhammad, N. Hydraulic performance of untreated and polymer-treated bentonite in inorganic landfill leachates. Clays Clay Miner. 2002, 50, 546-552. [CrossRef]

126. Razakamanantsoa, A.R.; Barast, G.; Djeran-Maigre, I. Hydraulic performance of activated calcium bentonite treated by polyionic charged polymer. Appl. Clay Sci. 2012, 59-60, 103-114. [CrossRef]

127. Scalia, J.; Benson, C.H.; Bohnhoff, G.L.; Edil, T.B. Long-Term Hydraulic Conductivity of a Bentonite-Polymer Composite Permeated with Aggressive Inorganic Solutions. J. Geotech. Geoenviron. Eng. 2014, 140, 4013025. [CrossRef]

128. Fujida, A. Evaluation of the Behavior of Newly Developed Water Absorption Debio-Materials; Report of National Institute of Technology; Tomakomai College: Tomakomai, Japan, 2014. Available online: http://www. tomakomai-ct.ac.jp (accessed on 6 November 2017). (In Japanese)

(C) 2017 by the authors. Licensee MDPI, Basel, Switzerland. This article is an open access article distributed under the terms and conditions of the Creative Commons Attribution (CC BY) license (http://creativecommons.org/licenses/by/4.0/). 